\title{
Geographical distribution database of freshwater fishes from Argentina
}

Jorge Liotta (i)
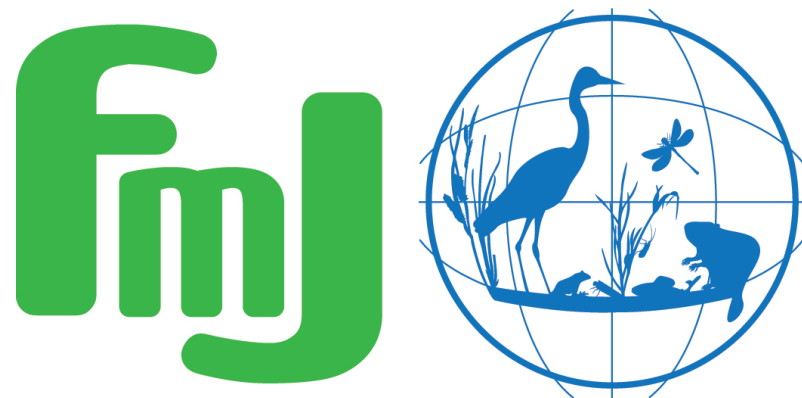

Freshwater Metadata Journal 



\title{
Geographical distribution database of freshwater fishes from Argentina
}

\author{
Jorge Liotta ${ }^{1}$
}

1 Museo de Ciencias Naturales A. Scasso, San Nicolás de los Arroyos, Argentina; corresponding author: jorgerliotta@gmail.com

Please cite this paper as follows: Liotta, J., 2020. Geographical distribution database of freshwater fishes from Argentina. Freshwater Metadata Journal 47: 1-5. https://doi.org/10.15504/fmj.2020.47

Received: 2019-12-13 / Published: 2020-02-11

\section{Keywords}

fishes, freshwater, argentina, database, distribution

\section{Short description of the dataset/summary}

The main objective of this database is to compile and publish high-quality, georeferenced information on the distribution of inland fish from the Argentine Republic. It has fields of information of various types: systematic and conservation status (23 fields), geographical (16), literature (12), georeferencing and associated quality (12), and collection (3). It currently has 19,000 records of nearly 550 valid native and 24 exotic species, which were scattered across 800 scientific publications and museum collections. 30\% of the records correspond to specimens while the rest of the records are observational.

\section{Short description of the dataset/summary (original/national language)}

El objetivo central de esta base de datos es compilar y publicar información, georreferenciada y de alta calidad, sobre la distribución de los peces de aguas continentales de la República Argentina. Posee campos de información de diversos tipos: de sistemática y status de conservación (23 campos), geográficos (16), de bibliografía (12), de georreferenciación y calidad asociada (12), y de colección (3). Actualmente cuenta con unos 19.000 registros de casi 550 especies nativas y 24 exóticas válidas, que se encontraban dispersos en más de 800 publicaciones científicas y varias colecciones de museos. Un $30 \%$ de los registros corresponden a especímenes mientras que el resto de los registros son observacionales.

\section{General information}

dataset entry ID:

\section{name of the dataset:}

full name of the dataset:

full name of the datast (original/national language):

\section{FWM 27}

Freshwater Fishes from Argentina

Distribución geográfica de los peces de aguas continentales de Argentina 
dataset short name: BasePecesArg

type of dataset: species distribution data

data type: point data/observation data

science keywords according to GCMD:

topic: Terrestrial Hydrosphere

ISO topic category according to ISO 19115:

Biota, Geoscientific Information, Inland Waters, Location

INSPIRE keywords according to GEMET:

Administrative units, Bio-geographical regions, Geographical names, Habitats and biotopes, Hydrography, Species distribution

own science keywords: Argentina, freshwater fishes, distribution

funding:

Museo de Ciencias Naturales "A. Scasso"

\section{Technical and administrative specifications}

$\begin{array}{ll}\text { data format: } & \text { Excel } \\ \text { operating system: } & \text { Win 7 } \\ \text { data language: } & \text { Spanish } \\ \text { current access level: } & \text { web (public) } \\ \text { web address: } & \text { www.pecesargentin } \\ \text { others/details: } & \text { Not all fields are av } \\ & \text { infobasepecesarg@ } \\ \text { currently available through GBIF: } & \text { no } \\ \text { exchange planned: } & \text { yes } \\ \text { data in data repository: } & \text { yes } \\ \text { specify repository: } & \text { Ictioplata (partial) }\end{array}$

Do you plan to publish the data on the Freshwater Biodiversity Data Portal:

$\begin{array}{ll}\begin{array}{l}\text { update level: } \\ \text { documentation: } \\ \text { type: }\end{array} & \text { continuously updated } \\ \text { language: } & \text { manual } \\ & \text { Spanish } \\ \text { contact details: } & \\ \text { metadata contact person: } & \\ \text { first, last name: } & \text { Jorge Liotta } \\ \text { phone: } & +5493364639246 \\ \text { email: } & \text { jorgerliotta@gmail.com } \\ \text { institution: } & \text { Museo de Ciencias Naturales "A. Scasso" } \\ \text { address: } & \text { Don Bosco 580 } \\ \text { postal code, city: } & 2900 \text { San Nicolás de los Arroyos } \\ \text { province, state: } & \text { Buenos Aires } \\ \text { country } & \text { Argentina } \\ \text { web address: } & \text { www.museoscasso.com.ar } \\ \text { technical contact person: } & \\ \text { first, last name: } & \text { Jorge Liotta } \\ \text { phone: } & +5493364639246 \\ \text { email: } & \text { infobasepecesarg@gmail.com } \\ \text { scientific contact person: } & \\ \text { first, last name: } & \text { Jorge Liotta }\end{array}$


phone:

email:
+5493364639246

jorgerliotta@gmail.com

\section{Intellectual property rights and citation \\ dataset creator (data compiler): \\ contact name: \\ Jorge Liotta \\ contact email: \\ jorgerliotta@gmail.com \\ contact institution: \\ Museo de Ciencias Naturales "A. Scasso"}

data contributors to/owners of this dataset:

single

criteria for using this dataset: The dataset needs to be requested from dataset creator with specific conditions of use.

other/additional criteria:

Certain fields of the dataset are available in a website

(www.pecesargentina.com.ar), free of charge, with prior login. A distribution map for the selected species is shown.

Users can request more data by contacting infobasepecesarg@gmail.com.

citation of this dataset:

author(s):

Liotta, J.

title and journal (name, number, pages):

Base de datos de peces de aguas continentales de Argentina. Published on:

http://www.peceargentina.com.ar. Accessed on [dd/mm/yyyy].

year:

2019

citation of the metadata:

author(s):

Liotta J.

title and journal (name, number, pages):

Geographical distribution database of freshwater fishes from Argentina.

Freshwater Metadata Journal 47: 1-5

year:

2020

doi:

https://doi.org/10.15504/fmj.2020.47

dataset related references:

reference 1:

author(s):

title:

Liotta, J.

Distribución geográfica de los peces de aguas continentales de la República Argentina, PROBIOTA Serie Documentos N 3, FCNyM, UNLP - Fundación Óga - Museo de Ciencias Naturales Rvdo. P. Antonio Scasso, 701 pp, Buenos Aires.

year:

2006

\section{General data specifications}

regional coverage of the dataset:

spatial extent of the dataset:

national

continents:

South America

\section{spatial extent (bounding coordinates):}

southernmost latitude $\left[{ }^{\circ}\right]$ :

$-68,5688889$

northernmost latitude $\left[^{\circ}\right]$ :

westernmost longitude $\left[{ }^{\circ}\right.$ :

easternmost longitude $\left[^{\circ}\right]$ : 
minimum altitude:

maximum altitude:

countries:
0 metres

4000 metres

South America: Argentina

world climatic regions according to Köppen:

Group B: dry (arid and semiarid) climates

Group C: temperate/mesothermal climates

Group D: continental/microthermal climate

Group E: polar climates

freshwater ecoregions of the world (FEOW) according to WWF:

South America: Bonaerensean Drainages, Chaco, Cuyan - Desaguadero, Iguassu, Lower Parana, Lower Uruguay, Mar Chiquita - Salinas Grandes, Patagonia, Upper Parana, Upper Uruguay, Valdivian Lakes

ecosystem type:

covered timeframe:

\section{Site specifications}

coordinate system/grid data: datum (e.g. WGS84):

grid data available:

site coding available:

number of sites:

exact number of sites:

comments:

\section{Biological data}

biological data origin:

comments:

organism group addressed: latitude/longitude, format: DD

WGS84

no

no

$>1000$

2883

The sites are defined here concatenating decimal latitude and decimal longitude. Locality, province, water body, basin, etc. are completed for each record.

general compilation,

literature survey, compilation of existing databases, museum collections Most of the data comes from scientific literature (more than 800 compiled papers), collections of Argentine and foreign museums have also been loaded. fish

\section{Sample resolution}

fish:

taxonomic resolution:

level:

species

percentage of species level data:

99

taxonomic coding:

taxalist according to:

reference(s):

Eschmeyer's Catalog of Fishes

Fricke, R., Eschmeyer, W. N. \& Van der Laan, R. (eds) 2019. Eschmeyer's Catalog of Fishes: genera, species, references.

(http://researcharchive.calacademy.org/research/ichthyology/catalog/fishcatma in.asp). Electronic version accessed $13 \mathrm{dec} 2019$.

sample specifications: 


\section{Other specifications}

\section{GIS layers, shape files related to the dataset:}

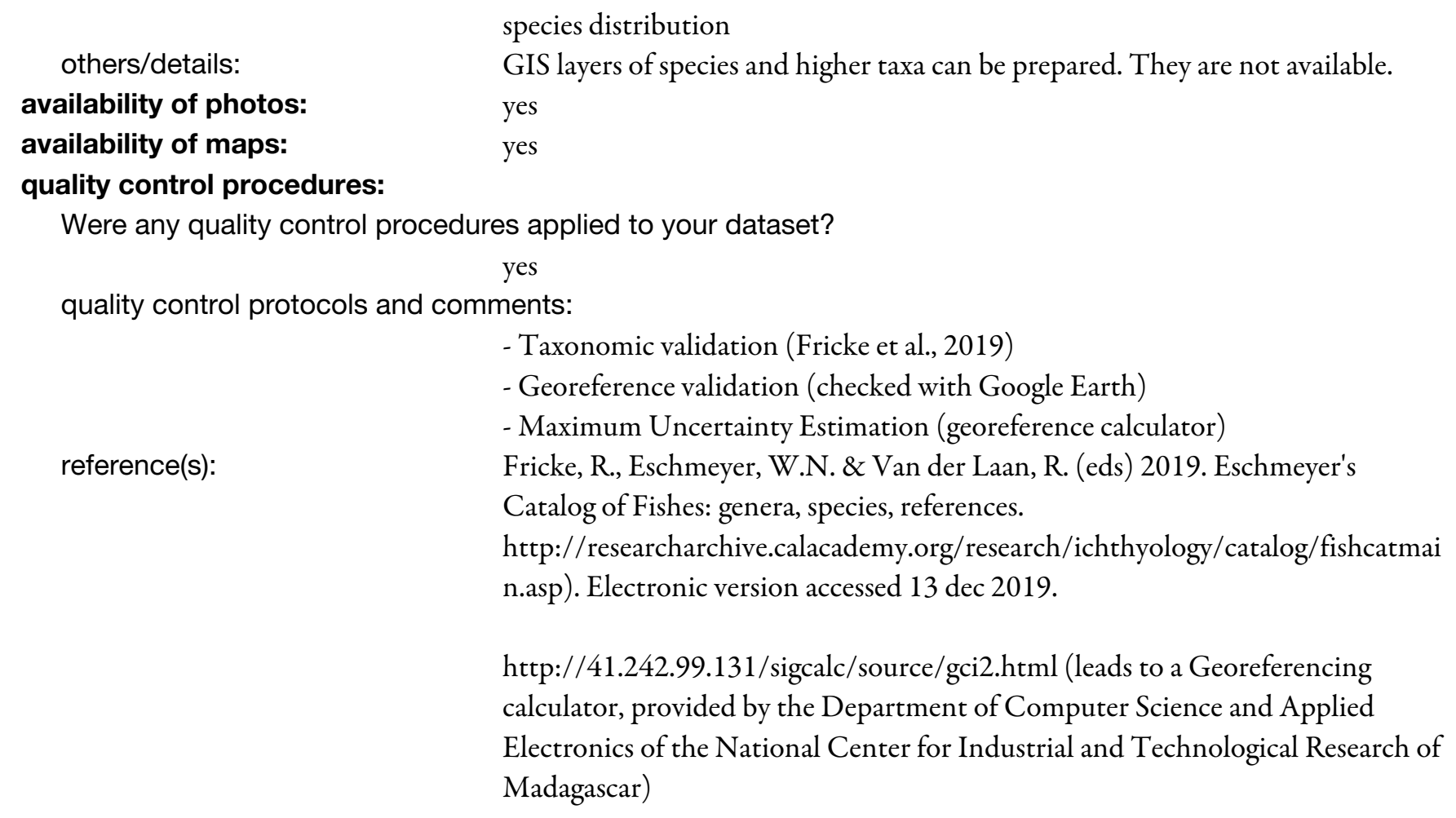

\section{Acknowledgements}

To the Vertebrate Zoology Division of the La Plata Museum, especially Dr. Hugo López, for his invaluable help. To the Ministry of Agriculture, Livestock, Fisheries and Food of the Argentine Republic that in 2006 financed the publication of the first edition of the book generated by this database. To the Inter American Biodiversity Information Network (IABIN) that in 2010 financed the incorporation of georeferencing quality fields. To Daniel Torres, from Hostool, for his essential collaboration for online publishing.

\section{References}

Liotta, J., 2006. Distribución geográfica de los peces de aguas continentales de la República Argentina, PROBIOTA Serie Documentos N³, FCNyM, UNLP - Fundación Óga - Museo de Ciencias Naturales Rvdo. P. Antonio Scasso, 701 pp, Buenos Aires. 